\title{
legelivet
}

På disse nye sidene i Tidsskriftet - legelivet - finner du stoff om legers liv.

Her er det presentasjon av arbeidssteder, nyhetssaker, nye doktorgrader,

nye spesialister, nyansettelser, prisutdelinger og minneord.

Alt samlet på ett sted - så du kan følge enda bedre med.

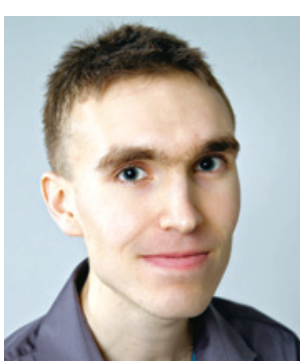

Frederik Emil Juul. Foto: Einar Nilsen

Frederik Emil Juul (f. 1989) er medisinstudent ved Universitetet i Oslo og redaktør i medisinstudentmagasinet AEsculap.

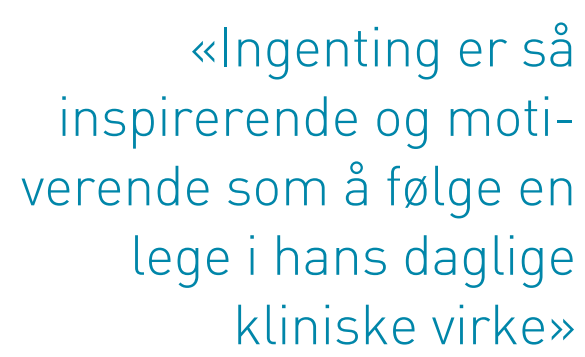

«lngenting er så inspirerende og motilege i hans daglige kliniske virke»

\section{Takk for dekket bord!}

\author{
Hvorfor hospiterer ikke flere studenter utenfor undervisningstiden? \\ Jeg har møtt engasjerte og positive leger som gjerne deler sin kunnskap.
}

Å være medisinstudent er på flere måter en luksustilværelse. I tillegg til det oppsatte studieprogrammet er hele sykehuset tilgjengelig for studenten, som kan ferdes nærmest hvor han vil uten å måtte være på samme sted et helt vaktskift, skrive journaler eller gjøre papirarbeid. Det er som å forflytte seg mellom dekkede bord og en ypperlig anledning til å se mange pasienter, tilstander og prosedyrer, hvorav flere er eneste mulighet gjennom hele legelivet.

Dessuten mener jeg ingenting er så inspirerende og motiverende som å følge en lege i hans daglige kliniske virke og få knyttet fagstoffet opp mot konkrete pasienter. For eksempel tanken «Hadde jeg kunnet mer om pankreatitt, ville jeg ikke glemt å vurdere kalsiumnivået!», øvelsen i å auskultere mange hjertepasienter og opplevelsen av tydelige hallusinasjonstegn som bivirkning til ketamin. Personlig vil jeg aldri glemme min første kveld med en anestesilege, hvor jeg måtte løpe med operasjonssko etter beste evne. Tilsynelatende krever dette en egen teknikk jeg fremdeles ikke forstår og enda mindre behersker.

Jeg blir ofte imponert over hvor villige legene er til å forklare og demonstrere underveis. Flere har samme erfaring som meg (1). De få gangene jeg er blitt avvist, har det vært fullt forståelig - vedkommende lege driver nærmest hjertekompresjon av pasienten, altså ganske taktløst fra min side.
Derfor er det et lite mysterium for meg hvorfor flertallet legestudenter - tilsynelatende - ikke benytter seg av muligheten til å hospitere på egen hånd. Jeg tror ikke det skyldes en manglende interesse for faget, men kanskje mener de fleste utbyttet er for lite eller at hverdagen med barnehagehenting og deltidsjobb er travel nok. Selv velger jeg å tro at for få kjenner til muligheten, for utenfor undervisningstiden er det ikke folksomt med studenter. Kanskje er det grunnen til at legene er så positivt innstilt til de få som tar kontakt?

På den annen side er det obligatorisk klinisk undervisning innlemmet $i$ den normerte studieplanen. Det er ikke slik at studentene går gjennom studiet uten å møte pasienter. Likevel, med fem-seks studenter per pasient sier det seg selv at situasjonen blir ekstra kunstig og mengdetreningsmulighetene begrenset.

Derfor takker jeg alle leger og helsearbeidere for bidraget til det dekkede kunnskapsbordet $\mathrm{og}$ håper at jeg $\mathrm{i}$ fremtiden kan dele plass med flere medstudenter, i et positivt og lærerikt selskap hvor den viktigste deltakeren er - og skal være - pasienten.

\footnotetext{
Litteratur

1. Iversen JM. Et fantastisk studium. Tidsskr Nor Legeforen 2012; 132: 1778-9.
} 